\title{
Üniversite Öğrencilerinin Boş Zaman Değerlendirme Etkinliklerine Katılımlarında Etkili Olan Faktörlerin Belirlenmesi: Hitit Üniversitesi İ.İ.B.F. Öğrencileri Üzerine Bir Araştırma
}

Öz

Üniversiteler, ülkesine ve topluma yararl ve mesleklerinde iyi eğitilmiş bireyler yetiştirmeyi hedeflemektedirler. Üniversite öğrencileri aldıkları eğitim sayesinde gelecekte yer alacakları konumlar göz önünde bulundurulduğunda, üniversite ögrencilerini toplumun dinamiklerini belirleyecek aday kişiler şeklinde ifade etmek mümkündür. Bu nedenle üniversite öğrencilerinin sadece mesleki açıdan kendilerini geliştirmeleri yeterli değildir. Mesleki eğitimin yanı sira sosyal, fiziksel ve psikolojik açıdan da kendilerini geliştirmeleri oldukça önemlidir. Üniversite ögrencilerinin sosyal, fiziksel ve psikolojik açıldan kendilerini geliştirmeleri ise boş zamanlarını etkin bir şekilde değerlendirmeleri ile sağlanabilir. Üniversite ögrencilerin boş zamanları, eğitim, uyku ve dinlenme süresi dışında kalan zamanlardır. Bu çalışmanın amacı üniversite öğrencilerinin boş zaman değerlendirme etkinliklerine katılımlarında etkili olan faktörlerin değerlendirilerek tercih edilen etkinlik türlerine göre kümeleme analizinin gerçekleştirilmesidir.
\end{abstract}

Anahtar Kelimeler: Boş zaman, boş zaman değerlendirme etkinlikleri, üniversite öğrencileri, Hitit Üniversitesi.

\section{Determination of The Effective Factors in The Participation of University Students in The Leisure Time Activities: A Research on Students of Hitit University Business and Administration Faculty}

\begin{abstract}
Universities aim to raise individuals who are beneficial to their country and society and who are well trained in their professions. It is possible to express university students as candidates who will determine the dynamics of the society, considering the future positions of university students thanks to their education. For this reason, it is not enough for university students to develop themselves only professionally. It is very important for them to improve themselves in terms of social, physical and psychological as well as vocational education. University students' social, physical and psychological development can be provided by evaluating their spare time effectively. University students' leisure time is the time outside of education, sleep and rest. The aim of this study is to evaluate the factors that affect the participation of university students in leisure activities and to perform cluster analysis according to the preferred activity types.
\end{abstract}

Keywords: Leisure time, leisure time activities, university students, Hitit University.

*ORCID Prof. Dr., Hitit Üniversitesi, İIBF, İşletme Bölümü, sabihakilic@hitit.edu.tr

** ORCID Dr. Öğr. Üyesi, Hitit Üniversitesi, İ̈BF, İşletme Bölümü, kmugedaldal@hitit.edu.tr 


\section{EXTENDED ABSTRACT}

Universities aim to raise individuals who are beneficial to their country and society and who are well trained in their professions. It is possible to express university students as candidates who will determine the dynamics of the society, considering their future positions thanks to the education they receive. Therefore, it is not enough for university students to develop themselves only professionally. It is very important for them to improve themselves in terms of social, physical and psychological as well as vocational education. University students' social, physical and psychological development can be provided by evaluating their spare time effectively. University students' leisure time is the time outside of education, sleep and rest. The aim of this study is to evaluate the factors that affect the participation of university students in leisure activities and to perform cluster analysis according to the preferred activity types. Study data were obtained through questionnaires applied to students studying at the Faculty of Economics and Administrative Sciences at Hitit University. In the scope of the study, percentage, frequency and cross-tab analysis were used in the evaluations regarding the demographic characteristics of the students, their level of education, the types of activities they prefer, the frequency of their participation in the activities, the factors that were effective in choosing their activity types, and the factors that were effective in their participation in the activities. Two-stage cluster analysis was used to create cluster groups of students' leisure time activities.

According to the results of the analysis, in order to evaluate the leisure time of the students, they prefer activities such as reading books, listening to music and going for tours such as bazaar, market, park, and at least watching sports competitions in the facilities and participating in cultural / scientific activities. $61.1 \%$ of the students stated that they were doing activities to evaluate their free time at least three days a week. It is seen that the appropriate time of the students in choosing the leisure time activity types and the factors of feeling comfortable are very effective, and the health programs on television are very low. The students stated that they participated in leisure activities to get new ideas, to stay away from stress and tension and to take their time out of routine.

As a result, individuals prefer various activities to use their spare time effectively and efficiently. In these preferences of individuals, demographic characteristics, educational status, frequency of benefiting from activities, preference of activities and levels of participation in activities are effective. In this study, cluster analysis was used to determine the factors that are effective in determining leisure time activities. Considering the findings obtained as a result of the study analysis, it can be suggested that students develop social, psychological and physical activities by considering the factors affecting their leisure time activity preferences and preferences in order to create brand cities and brand universities for the administrative managers of cities and higher education institutions. 


\section{Giriş}

Dünya değerlerinin değişimi, insanların değer yargılarını ve yaşam şekillerinde de değişikliklere neden olmuştur ve var olan kullanım alanları farklılaştırılmış ya da yeni kullanım alanları oluşturulmuştur. Sanayileşme, teknolojinin gelişmesi, sosyal ve ekonomik koşullarda yaşanan değişimler şehirlerde yaşayan insanları, psikolojik ve fiziksel açıdan kendilerini geliştirebilecekleri çeşitli etkinlikler arayışına sokmuştur. İnsanların robotlaştı̆ğ günümüz koşullarında, şehir yaşamının gürültüsünden kurtulup, psikolojik ve fiziksel yorgunluklardan kurtulmak isteyen bireyler stresten uzaklaşmak ve zamanlarını keyifli bir şekilde geçirmek için rekreatif etkinlikleri değerlendirmektedirler (Karatoprak vd., 2012). İnsanların ruhsal ve bedensel olarak yenilenmesini sağlayan rekreasyon, bireysel ve toplumsal değerler yönünden mutluluk, keyif, bunalımdan uzaklaşma ve bunların dışında birçok değer katan bir kavram olarak kabul edilmektedir (Karaküçük, 2008).

Boş zaman; bireylerin kendileri ve çevresindeki diğer insanlar için sorumluluk ve bağlantılardan kurtulduğu ve gönüllü bir şekilde seçeceğe etkinliklere ayıracağı zaman şeklinde tanımlanmaktadır (Tezcan, 1972). Başka bir tanıma göre boş zaman, insanların çalışmadığı, yaşamsal zorunluluklarının ve görevlerinin haricinde kendi istedikleri şekilde geçirebilecekleri zaman şeklinde ifade edilmektedir (K1lbaş, 2004).

Boş zaman kavramı çoğu zaman serbest zaman, çalışma dışı zaman ve rekreasyon kavramı ile karıştırılabilmektedir. Karaküçük (2008) bu karışıklığı önlemek için kavramları şu şekilde açıklamıştır: Çalışma dışı zaman, hayatı kazanmak amacıyla bedensel ve düşünsel çabalar için harcanan zorunlu zamanın dışında kalan zamanı oluşturmaktadır. Çalışma dışı zaman; çocuk serbest zamanı, biyolojik olarak yaşamak için yapılması gereken yemek, uyumak, kişisel ihtiyaçların karşılanması, işe gidiş - geliş süreleri, bakımı ile zorlama duygusunun en az olduğu insanın kendi yarg1 ve seçimine göre kullanacağı isteğe bağlı kullandığı boş zamanı kapsamaktadır. Boş zaman, insanın işinden artakalan serbest zaman içerisinde yer alan kişinin her türlü bağımlılıktan ve bağl1lıktan kurtularak özgürce kullanacağ bir zaman kesimini ifade etmektedir. Ayrıca serbest zamanda herhangi bir yönlendirme bulunmamakta, boş zaman ise, yönlendirilmeye açık potansiyel içermektedir. Rekreasyon da boş zamanın belirli kullanış biçimlerini oluşturmakta ve serbest zaman içinde oluşan boş zaman alanında, bireyin özgürce seçip uyguladığ 1 aktiviteler rekreasyonu oluşturmaktadır. Bucher (1972) ise boş zaman ile serbest zaman arasındaki farkı şu şekilde açıklamaktadır. Her insanın serbest zamanı olabilmekte ancak boş zamanı olmaya bilmektedir (Karaküçük, 2008).

Toplumsal güçlenmenin, bütünlüğün, sosyalleşmenin ve sürdürülebilirliğin sağlanabilmesi için rekreasyon toplumsal bir ihtiyaç; kişilerin zorunlu işleri dışında kalan sürede zevk aldıkları farklı bir faaliyette bulunarak, dinlenmeleri, eğlenmeleri ve kendilerini yenileyebilmeleri gibi birçok nedenle de kişisel bir ihtiyaçtır. Rekreasyona duyulan kişisel ihtiyaçları; fiziki sağlık gelişimi yaratmak, ruh sağlığını korumak ve sürdürülmesine katkı sağlamak, kişisel beceri ve yeteneğin gelişmesine yardımcı olmak, yaratıcılığı geliştirmek, insanı sosyalleştirmek, çalışma başarısı ve iş verimini arttırmak, ekonomik hareketi geliştirmekte ve insanı mutlu etmektedir şeklinde sıralamak mümkündür (Erenci, 2006; Mengütay ve Ağılönü, 2009). Toplumsal dayanışma ve bütünleşmeyi sağlamak ve demokratik toplumun yaratılmasına imkân sağlamak ise rekreasyonel etkinliklere toplum tarafından duyulan ihtiyaçlardır (Tezcan, 1977).

Boş zamanların pozitif bir şekilde değerlendirilmesi toplumun güçlenmesi için etkili olabileceği gibi, genç bireylerin zararlı alışkanlıklardan uzak durmasını da sağlayabilecektir. $\mathrm{Bu}$ nedenle üniversite öğrencilerinin boş zamanları nasıl geçirdiklerinin belirlenmesi birçok araştırmacı tarafından önemli bulunmuştur (Sabbağ ve Aksoy, 2011). Kır (2007) çalışmasında 
boş zamanın, bireyin kişiliğinin gelişmesinde, toplumsal refah ve kalkınmanın sağlanmasındaki rolüne dikkat çekerek, üniversite öğrencilerinin pasif boş zaman değerlendirme alışkanlıklarının, ülke refahının artmasına katkı sağlamaktan uzak olduğunu, bunun yanında gençlerin kimlik gelişimlerini de olumsuz etkileyebileceğini bildirmiştir. Ayrıca üniversite öğrencilerinin boş zamanlarında en çok tercih ettikleri etkinliklerin spor yapma, kantinde zaman geçirme, müzikle uğraşma, arkadaşlarıyla gezme ve kahveye gitme şeklinde olduğunu saptamıştır.

Terzioğlu ve Yazıcı (2003), Atatürk üniversitesinde eğitim görmekte olan öğrencilerin boş zaman değerlendirme anlayış ve alışkanlık düzeylerini belirlemeye çalıştıkları çalışmaların, öğrencilerin değerlendirilebilecek çok fazla boş zamanları bulunduğu ancak bunu etkili bir şekilde değerlendirmedikleri sonucuna ulaşmışlardır. Ayrıca öğrencilerin boş zamanları değerlendirme etkinliklerinin belirlenmesinde demografik özelliklerin ve öğretim düzeyinin etkili olduğunu ifade etmişlerdir.

Tekin vd., (2008), Karaman Yüksek Öğrenim Kredi ve Yurtlar Kurumunda kalan üniversite öğrencilerinin boş zaman değerlendirme alışkanlıkları ve yurtların bu konuda yeterliliklerinin hangi düzeyde olduğunu belirlemek için yaptıkları çalışmada öğrencilerin boş zamanlarının bulunduğunu ancak yurtlarda bu zamanları değerlendirebilecekleri alternatifler bulunmadığı sonucuna ulaşılmıştır. Schrag ve Strattman (2009), yaptıkları çalışmada kent ve kırsal alanda yaşayan öğrencilerin müzik dinleme ve spor faaliyetlerine katılımlarının yüksek olduğunu belirlemişlerdir. Kırsal alanda eğitim gören öğrencilerin boş zamanlarını arkadaşlarıyla vakit geçirerek ve tv/film izleyerek; şehir merkezinde eğitim gören öğrencilerin ise, alışveriş yaparak, video ve bilgisayar oyunu oynayarak değerlendirdikleri sonucuna ulaşılmıştır.

\section{Yöntem}

Çalışmanın amacı, üniversite öğrencilerinin boş zaman değerlendirme etkinliklerine katılımlarında etkili olan faktörlerin değerlendirilerek tercih edilen etkinlik türlerine göre kümeleme analizinin gerçekleştirilmesidir. Bu amaçla, çalışmanın ana kütlesi Hitit Üniversitesi İIBF öğrencileri olarak belirlenmiştir. İktisadi ve İdari Bilimler Fakültesinde 2019 yılı itibariyle 2995 öğrenci eğitim görmektedir. Öğrencilerin \%49’u kadın, \%51'i erkek öğrencilerden oluşmaktadır. \%95 güven aralığında ve 0,05 hata düzeyinde oranlar yöntemiyle örnek hacmi aşağıdaki formül yardımıyla;

$$
n=\frac{N \cdot(p \cdot q) \cdot Z^{2}}{(N-1) \cdot E^{2}+(p \cdot q) \cdot Z^{2}} \quad n=\frac{2929(0,51 \times 0,49) \cdot 2^{2}}{(2929-1) \cdot(0,05)^{2}+(0,51 \times 0,49) \cdot 2^{2}}=351,92 \sim 352 \mathrm{n} / \mathrm{N}=0,12
$$

olduğundan

$$
n=\frac{n . N}{N+n-1}=n=\frac{352 \times 2929}{2929+352-1}=314
$$

öğrenci analize dahil edilmiştir.

Çalışma verilerinin elde edilmesinde yüz yüze anket tekniğinden yararlanılmıştır. Anket 4 bölüm ve 13 sorudan oluşmaktadır. Birinci bölüm öğrencilerin cinsiyet, yaş, gelir, ikamet yeri, ailenin aylık geliri gibi çoktan seçmeli demografik özellikleri belirlemeye yönelik sorular ile öğrencilerin bölüm, sınıf ve program türlerini belirlemeye yönelik çoktan seçmeli öğrenim 
düzeylerini belirlemeye yönelik sorulardan oluşmaktadır. İkinci bölüm öğrencilerin boş zamanlarını değerlendirmede tercih ettikleri etkinlik türünü ve etkinlik yapma sıklıklarını belirlemeye yönelik çoktan seçmeli sorulardan oluşmaktadır. Üçüncü bölüm öğrencilerin boş zaman değerlendirme etkinlik türünü seçmelerinde etkili olan faktörlerin belirlenmesine yönelik "Kesinlikle Katılmıyorum” ve "Kesinlikle Katılıyorum" arasında değişen 5'li likert ölçeğine göre belirlenmiş 10 ifadeden oluşmaktadır. İfadelerin belirlenmesinde Arslan (2010) çalışmalarından yararlanılmıştır. Dördüncü bölüm öğrencilerin boş zaman değerlendirme etkinliklerine katılımlarında etkili olan faktörleri belirlemeye yönelik "Kesinlikle Katılmıyorum" ve "Kesinlikle Katılıyorum" arasında değişen 5'li likert ölçeğine göre belirlenmiş 32 ifadeden oluşmaktadır. İfadelerin belirlenmesinde Beard ve Raghep (1980) çalışmalarından yararlanılmıştır.

Çalışma kapsamında geliştirilen kavramsal model aşağıda yer almaktadır:

Şekil 1: Boş Zaman Değerlendirme Etkinlikleri Kümeleme Analizine İlişkin Kavramsal Model

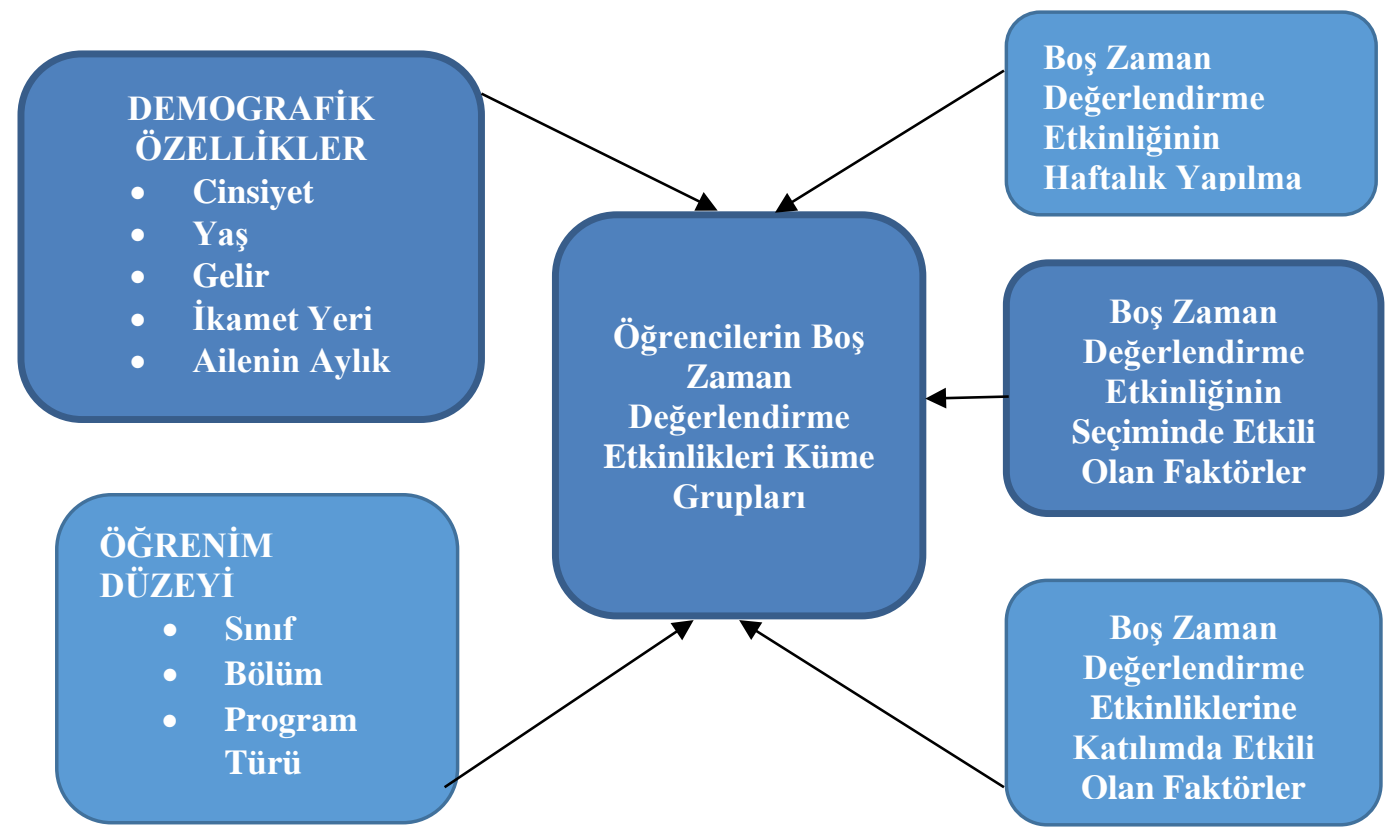

Şekil 1'de yer alan çalışmanın kavramsal modeline göre üniversite öğrencilerinin boş zaman değerlendirme etkinlikleri küme gruplarının oluşturulmasında, öğrencilerin demografik özellikleri, öğretim düzeyleri, boş zaman etkinliklerine katılma sıklıkları, etkinlik türlerini seçme ve etkinliklere katılmalarında etkili olan faktörlerin etkili olduğu söylenebilir. Çalışma kapsamında öğrencilerin demografik özellikleri, öğretim düzeyleri, tercih ettikleri etkinlik türleri, etkinliklerine katılım sıklıkları, etkinlik türlerini seçmelerinde etkili olan faktörler ile etkinliklere katılımlarında etkili olan faktörlere ilişkin değerlendirmelerde tanımlayıcı istatistiklerden yüzde ve frekans ile çapraz tablo analizlerinden yararlanılmıştır. Öğrencilerin boş zaman değerlendirme etkinlikleri küme gruplarının oluşturulmasında iki kademeli kümeleme analizi kullanılmıştır. Analiz sonuçları aşağıdaki bölümlerde ayrıntılı olarak değerlendirilmiştir. 


\subsection{Analiz ve Bulgular}

Ankete katılan öğrencilerin demografik özellikleri ile eğitim düzeylerine ilişkin yüzde ve frekans değerleri aşağıdaki tabloda özetlenmektedir:

Tablo 1: Katılımcıların Demografik Özelliklerine İlişkin Tanımlayıcı İstatistikler

\begin{tabular}{|c|c|c|c|c|c|}
\hline Cinsiyet & $\mathrm{N}$ & $\%$ & Bölüm & $\mathrm{n}$ & $\%$ \\
\hline Kadın & 236 & 68,6 & İşletme & 61 & 17,7 \\
\hline Erkek & 108 & 31,4 & İktisat & 72 & 20,9 \\
\hline Toplam & 344 & 100,0 & Maliye & 74 & 21,5 \\
\hline Yaş & $\mathrm{N}$ & $\%$ & SBKY & 63 & 18,3 \\
\hline $18-20$ & 89 & 25,9 & Bankacılık ve Finans & 74 & 21,5 \\
\hline $21-23$ & 233 & 67,7 & Toplam & 344 & 100,0 \\
\hline $24-26$ & 20 & 5,8 & Program Türü & $\mathrm{n}$ & $\%$ \\
\hline $27+$ & 2 & 0,6 & Normal Öğretim & 314 & 91,3 \\
\hline Toplam & 344 & 100,0 & İkinci Öğretim & 30 & 8,7 \\
\hline Gelir & $\mathrm{N}$ & $\%$ & Toplam & 344 & 100,0 \\
\hline 400 TL'den az & 80 & 23,3 & Sinif & $\mathrm{n}$ & $\%$ \\
\hline $401-600 \mathrm{TL}$ & 191 & 55,5 & 1. Sinif & 63 & 18,3 \\
\hline 601-800 TL & 35 & 10,2 & 2. Sinif & 88 & 25,6 \\
\hline $801-1000 \mathrm{TL}$ & 16 & 4,7 & 3. Sinif & 93 & 27,0 \\
\hline $1001+$ & 22 & 6,4 & 4. Sinif & 100 & 29,1 \\
\hline Toplam & 344 & 100,0 & Toplam & 344 & 100,0 \\
\hline Ailenizin Aylık Geliri & $\mathrm{N}$ & $\%$ & Ailenizin İkamet Ettiği Bölge? & $\mathrm{n}$ & $\%$ \\
\hline 1500 TL'den az & 37 & 10,8 & Marmara & 42 & 12,2 \\
\hline $1501-2500 \mathrm{TL}$ & 140 & 40,7 & Akdeniz & 22 & 6,4 \\
\hline $2501-3500 \mathrm{TL}$ & 90 & 26,2 & İç Anadolu & 101 & 29,4 \\
\hline $3501-4500 \mathrm{TL}$ & 38 & 11,0 & Karadeniz & 158 & 45,9 \\
\hline $4501+$ & 39 & 11,3 & Ege & 8 & 2,3 \\
\hline \multirow[t]{9}{*}{ Toplam } & 344 & 100,0 & Doğu Anadolu & 3 & 0,9 \\
\hline & & & G.Doğu Anadolu & 10 & 2,9 \\
\hline & & & Toplam & 344 & 100,0 \\
\hline & & & Ailenizin İkamet Ettiği Yer? & $\mathrm{n}$ & $\%$ \\
\hline & & & İl Merkezi & 173 & 50,3 \\
\hline & & & İlçe Merkezi & 116 & 33,7 \\
\hline & & & Kasaba & 8 & 2,3 \\
\hline & & & Köy & 47 & 13,7 \\
\hline & & & Toplam & 344 & 100,0 \\
\hline
\end{tabular}

Tablo 1'in verileri incelendiğinde, ankete katılan öğrencilerin \%69'unun kadın, \%31'inin erkek öğrencilerden oluştuğu, öğrencilerin \%94'ünün 24 yaşından küçük olduğu, \%66'sının 400 TL ila 800 TL arasında gelir düzeyine sahip oldukları, \%49'unun ailelerinin aylık gelirinin en az 2.500 TL olduğu, \%46'sının Karadeniz Bölgesi'nde ikamet ettikleri, \%50'sinin ailelerinin il merkezinde yaşadığı görülmektedir. Ankete katılan öğrencilerin \%18'inin 1. Sınıf, \%26'sının 2. Sınıf, \%27'sinin 3. Sınıf ve \%29'unun dördüncü sınıf öğrencilerinden oluştuğu, \%18'inin İşletme, \%21'inin İktisat, \%22'sinin Maliye, \%18'inin SBKY ve \%22'sinin de Bankacılık ve Finans bölümlerinde öğrenim gördükleri söylenebilir. Aşağıdaki tabloda öğrencilerin boş zamanlarını değerlendirdikleri etkinlik türlerine dair yüzde ve frekans değerleri yer almaktadır: 
Tablo 2: Öğrencilerin Boş Zamanlarını Değerlendirdikleri Etkinliklere İlişkin Tanımlayıcı İstatistikler

\begin{tabular}{|l|l|l|}
\hline Etkinlik Türü & $\mathrm{n}$ & $\%$ \\
\hline Kitap, gazete okurum. & 64 & 18,6 \\
\hline Müzik dinlerim. & 64 & 18,6 \\
\hline TV izlerim. & 35 & 10,2 \\
\hline Sinema ve Tiyatroya giderim. & 20 & 5,8 \\
\hline Çarşı, pazar, fuar, park gibi gezintilere çıkarım. & 55 & 16,0 \\
\hline Aktif olarak spor yaparım. & 29 & 8,4 \\
\hline Beceri gerektiren el işleri ve sanatla uğraşırım. & 16 & 4,7 \\
\hline Spor yarışmalarını tesislere giderek izlerim. & 1 & 0,3 \\
\hline Sosyal ve toplumsal faaliyetlerle uğraşırım. & 8 & 2,3 \\
\hline Kültürel ve bilimsel faaliyetlere katılırım. & 3 & 0,9 \\
\hline Kafeye giderim. & 17 & 4,9 \\
\hline Belli bir şeyle uğraşmam. & 13 & 3,8 \\
\hline Arkadaş ziyaretlerine giderim. & 6 & 1,7 \\
\hline $\begin{array}{l}\text { Sosyal sorumluluk faaliyetleri yaparım (ONKO-SAV, KAN-DER, } \\
\text { TEGV, Sevgi Evleri vb.) }\end{array}$ & 13 & 3,8 \\
\hline Toplam & 344 & 100,0 \\
\hline
\end{tabular}

Tablo 2'nin verileri incelendiğinde, öğrencilerin boş zamanlarını değerlendirmede tercih ettikleri ilk üç etkinliğin sırasıyla kitap, gazete okuma ve müzik dinleme $(\% 18,6)$ ile çarş1, pazar, fuar, park gibi gezintilere çıkma $(\% 16,0)$ olduğu görülmektedir. Öğrencilerin boş zamanlarını değerlendirmek amacıyla en az tercih ettikleri üç etkinlik ise sırasıyla spor yarışmalarını tesislerde izleme $(\% 0,3)$, kültürel ve bilimsel faaliyetlere katılma $(\% 0,9)$ ve arkadaş ziyaretlerinde bulunma $(\% 1,7)$ 'dır. Aşağıdaki tabloda ankete katılan öğrencilerin haftalık boş zaman değerlendirme etkinlik sıklıklarına ilişkin yüzde ve frekans değerleri yer almaktadir:

Tablo 3: Öğrencilerin Haftalık Boş Zaman Değerlendirme Etkinlik Sıklıklarına İlişkin Tanımlayıc İstatistikler

\begin{tabular}{|l|l|l|}
\hline Haftalık Gün Sayısı & $\mathbf{n}$ & $\mathbf{\%}$ \\
\hline Haftada bir gün & 40 & 11,6 \\
\hline Haftada iki gün & 94 & 27,3 \\
\hline Haftada üç gün & 88 & 25,6 \\
\hline Haftada dört gün & 42 & 12,2 \\
\hline Haftada beş gün & 32 & 9,3 \\
\hline Haftada altı gün & 10 & 2,9 \\
\hline Haftada yedi gün & 38 & 11,0 \\
\hline Toplam & 344 & 100,0 \\
\hline
\end{tabular}

Tablo 3'ün verileri incelendiğinde, ankete katılan öğrencilerin \%11'inin haftanın 7 günü boş zaman değerlendirme etkinliğinde bulundukları, \%12'sinin ise haftada sadece bir gün boş zaman etkinliğinde bulundukları görülmektedir. Aşağıdaki tabloda ankete katılan öğrencilerin boş zaman değerlendirme etkinlik türünü seçmelerinde etkili olan faktörlere ilişkin yüzde ve frekans değerleri yer almaktadır: 
Tablo 4: Öğrencilerin Boş Zaman Değerlendirme Etkinlik Türünü Seçimlerinde Etkili Olan

Faktörlere İlişskin Tanımlayıcı İstatistikler

\begin{tabular}{|l|l|l|l|l|l|l|}
\hline $\begin{array}{l}\text { Etkinlik Türü Seçiminde Etkili Olan } \\
\text { Faktörler }\end{array}$ & $\begin{array}{l}1 \\
\mathrm{n} / \%\end{array}$ & $\begin{array}{l}2 \\
\mathrm{n} / \%\end{array}$ & $\begin{array}{l}3 \\
\mathrm{n} / \%\end{array}$ & $\begin{array}{l}4 \\
\mathrm{n} / \%\end{array}$ & $\begin{array}{l}5 \\
\mathrm{n} / \%\end{array}$ & $\begin{array}{l}\text { Toplam } \\
\mathrm{n} / \%\end{array}$ \\
\hline Yaşıma uygun olmas1 & $42 / 12,2$ & $30 / 8,7$ & $44 / 12,8$ & $132 / 38,4$ & $96 / 27,9$ & $344 / 100,0$ \\
\hline Yeteneklerime uygun olmas1 & $35 / 10,2$ & $49 / 14,2$ & $56 / 16,3$ & $115 / 33,4$ & $89 / 25,9$ & $344 / 100,0$ \\
\hline Maliyetinin yüksek olmaması & $40 / 11,6$ & $26 / 7,6$ & $60 / 17,4$ & $110 / 32,0$ & $108 / 31,4$ & $344 / 100,0$ \\
\hline Zamanının uygun olması & $24 / 7,0$ & $10 / 2,9$ & $35 / 10,2$ & $155 / 45,1$ & $120 / 34,9$ & $344 / 100,0$ \\
\hline Yerinin uygun olması & $29 / 8,4$ & $15 / 4,4$ & $62 / 18,0$ & $125 / 36,3$ & $113 / 32,8$ & $344 / 100,0$ \\
\hline TV'deki sağliklı yaşam programları & $83 / 24,1$ & $61 / 17,7$ & $100 / 29,1$ & $63 / 18,3$ & $37 / 10,8$ & $344 / 100,0$ \\
\hline Doktor tavsiyesi & $84 / 24,4$ & $54 / 15,7$ & $89 / 25,9$ & $82 / 23,8$ & $35 / 10,2$ & $344 / 100,0$ \\
\hline Daha önce katıllanların tavsiyeleri & $56 / 16,3$ & $43 / 12,5$ & $84 / 24,4$ & $119 / 34,6$ & $42 / 12,2$ & $344 / 100,0$ \\
\hline Ortamda kendimi rahat hissediyorum & $25 / 7,3$ & $17 / 4,9$ & $48 / 14,0$ & $121 / 35,2$ & $133 / 38,7$ & $344 / 100,0$ \\
\hline Arkadaşlarıma eşlik etmem istiyorum & $39 / 11,3$ & $31 / 9,0$ & $56 / 16,3$ & $131 / 38,1$ & $87 / 25,3$ & $344 / 100,0$ \\
\hline
\end{tabular}

1: Kesinlikle Katılmıyorum; 2: Katılmıyorum; 3: Kararsızım; 4: Katılıyorum; 5: Kesinlikle Katılıyorum

Tablo 4’ün verileri incelendiğinde, ankete katılan öğrencilerin boş zaman değerlendirme etkinlik türlerini seçimlerinde etkili olan en önemli ilk üç faktörün sırasıyla zamanının uygun olması $(\% 80)$, ortamda kendilerini rahat hissetmeleri $(\% 73,9)$ ve yerinin uygun olması $(\% 69,1)$ olarak sıralanabilir. Öğrencilerin boş zamanlarını değerlendirmek için tercih ettikleri etkinlik türlerinin seçiminde en düşük etkiye sahip faktörün ise TV'deki sağlıklı yaşam programları $(\% 41,8)$ olduğu görülmektedir.

Tablo 5: Öğrencilerin Boş Zaman Etkinliklerine Katılımlarında Etkili Olan Faktörlere İlişkin

Tanımlayıcı İstatistikler

\begin{tabular}{|c|c|c|c|c|c|c|}
\hline Faktörler & $\begin{array}{l}1 \\
\mathrm{n} / \%\end{array}$ & $\begin{array}{l}2 \\
\mathrm{n} / \%\end{array}$ & $\begin{array}{l}3 \\
\mathrm{n} / \% \\
\end{array}$ & $\begin{array}{l}4 \\
\mathrm{n} / \% \\
\end{array}$ & $\begin{array}{l}5 \\
\mathrm{n} / \% \\
\end{array}$ & $\begin{array}{l}\text { Toplam } \\
\mathrm{n} / \%\end{array}$ \\
\hline $\begin{array}{l}\text { Etrafımdaki olaylardan haberdar olmak } \\
\text { için }\end{array}$ & $28 / 8,1$ & $42 / 12,2$ & $83 / 24,1$ & $129 / 37,5$ & $62 / 18,1$ & $344 / 100,0$ \\
\hline Merakımı gidermek için & $29 / 8,4$ & $35 / 10,2$ & $82 / 23,8$ & $133 / 38,7$ & $65 / 18,9$ & $344 / 100,0$ \\
\hline Yeni fikirler edinmek için & $16 / 4,7$ & $22 / 6,4$ & $33 / 9,6$ & $146 / 42,4$ & $127 / 36,9$ & $344 / 100,0$ \\
\hline $\begin{array}{l}\text { Kedim hakkında daha azla bilgi } \\
\text { edinmek için }\end{array}$ & $27 / 7,8$ & $25 / 7,3$ & $67 / 19,5$ & $125 / 36,3$ & $100 / 29,1$ & $344 / 100,0$ \\
\hline Bilgimi arttırmak için & $17 / 4,9$ & $23 / 6,7$ & $40 / 11,6$ & $130 / 37,8$ & $134 / 39,0$ & $344 / 100,0$ \\
\hline Yeni şeyler keşfetmek için & $17 / 4,9$ & $21 / 6,1$ & $38 / 11,0$ & $113 / 32,8$ & $155 / 45,1$ & $344 / 100,0$ \\
\hline Yaratıcı olmak için & $21 / 6,1$ & $17 / 4,9$ & $63 / 18,3$ & $126 / 36,6$ & $117 / 34,0$ & $344 / 100,0$ \\
\hline Hayal gücümü kullanmak için & $15 / 4,4$ & $29 / 8,4$ & $60 / 17,4$ & $120 / 34,9$ & $120 / 34,9$ & $344 / 100,0$ \\
\hline Başkaları ile arkadaşlık kurmak için & $39 / 11,3$ & $51 / 14,8$ & $85 / 24,7$ & $98 / 28,5$ & $71 / 20,6$ & $344 / 100,0$ \\
\hline $\begin{array}{l}\text { Diğerleri ile etkileşim halinde olmak } \\
\text { için }\end{array}$ & $38 / 11,0$ & $43 / 12,5$ & $86 / 25,0$ & $110 / 32,0$ & $67 / 19,5$ & $344 / 100,0$ \\
\hline Yakın dostluklar kurmak için & $33 / 9,6$ & $49 / 14,2$ & $97 / 28,2$ & $101 / 29,4$ & $64 / 18,6$ & $344 / 100,0$ \\
\hline Yeni ve farklı inanlarla tanışmak için & $39 / 11,3$ & $46 / 13,4$ & $73 / 21,2$ & $117 / 34,0$ & $69 / 20,1$ & $344 / 100,0$ \\
\hline $\begin{array}{l}\text { Düşüncelerimi, hislerimi ve fiziksel } \\
\text { yeteneklerimi ortaya çıkarmak için }\end{array}$ & $24 / 7,0$ & $25 / 7,3$ & $77 / 22,4$ & $126 / 36,6$ & $92 / 26,7$ & $344 / 100,0$ \\
\hline $\begin{array}{l}\text { Sosyal olarak yetenekli ve becerikli } \\
\text { olmak için }\end{array}$ & $27 / 7,8$ & $38 / 11,0$ & $62 / 18,0$ & $114 / 33,1$ & $103 / 29,9$ & $344 / 100,0$ \\
\hline Ait olma hissi elde etmek için & $54 / 15,7$ & $62 / 18,0$ & $86 / 25,0$ & $88 / 25,6$ & $54 / 15,7$ & $344 / 100,0$ \\
\hline Diğerlerinin saygısını kazanmak için & $75 / 21,8$ & $60 / 17,4$ & $80 / 23,3$ & $87 / 25,3$ & $42 / 12,2$ & $344 / 100,0$ \\
\hline Yeteneklerimi ispatlamak için & $55 / 16,0$ & $46 / 13,4$ & $84 / 24,4$ & $106 / 30,8$ & $53 / 15,4$ & $344 / 100,0$ \\
\hline $\begin{array}{l}\text { Yeteneklerimi göstermede iyi olmak } \\
\text { için }\end{array}$ & $39 / 11,3$ & $46 / 13,4$ & $76 / 22,1$ & $118 / 34,3$ & $65 / 18,9$ & $344 / 100,0$ \\
\hline $\begin{array}{l}\begin{array}{l}\text { Yeteneklerimi } \\
\text { geliştirmek için }\end{array} \\
\end{array}$ & $29 / 8,4$ & $32 / 9,3$ & $64 / 18,6$ & $126 / 36,6$ & $93 / 27,0$ & $344 / 100,0$ \\
\hline Aktif olmak için & $19 / 5,5$ & $17 / 4,9$ & $58 / 16,9$ & $140 / 40,7$ & $110 / 32,0$ & $344 / 100,0$ \\
\hline $\begin{array}{l}\begin{array}{l}\text { Fiziksel beceri } \\
\text { geliştirmek için }\end{array} \\
\end{array}$ & $24 / 7,0$ & $33 / 9,6$ & $71 / 20,6$ & $126 / 36,6$ & $90 / 26,2$ & $344 / 100,0$ \\
\hline Fiziksel şeklimi korumak için & $42 / 12,2$ & $31 / 9,0$ & $93 / 27,0$ & $114 / 33,1$ & $64 / 18,6$ & $344 / 100,0$ \\
\hline Fiziksel yeteneklerimi kullanmak için & $36 / 10,5$ & $40 / 11,6$ & $76 / 22,1$ & $124 / 36,0$ & $68 / 19,8$ & $344 / 100,0$ \\
\hline
\end{tabular}


Tablo 5 (Devamı): Öğrencilerin Boş Zaman Etkinliklerine Katılımlarında Etkili Olan

Faktörlere İlișkin Tanımlayıcı İstatistikler

\begin{tabular}{|l|l|l|l|l|l|l|}
\hline Fiziksel formumu geliştirmek için & $40 / 11,6$ & $37 / 10,8$ & $86 / 25,0$ & $114 / 33,1$ & $67 / 19,5$ & $344 / 100,0$ \\
\hline Hafiflemek için & $31 / 9,0$ & $45 / 13,1$ & $73 / 21,2$ & $111 / 32,3$ & $84 / 24,4$ & $344 / 100,0$ \\
\hline Bazen yalnız kalmay1 sevdiğim için & $32 / 9,3$ & $32 / 9,3$ & $62 / 18,0$ & $106 / 30,8$ & $112 / 32,6$ & $344 / 100,0$ \\
\hline Fiziksel olarak rahatlamak için & $25 / 7,3$ & $36 / 10,5$ & $45 / 13,1$ & $114 / 33,1$ & $124 / 36,0$ & $344 / 100,0$ \\
\hline Zihinsel olarak rahatlamak için & $18 / 5,2$ & $24 / 7,0$ & $42 / 12,2$ & $112 / 32,6$ & $148 / 43,0$ & $344 / 100,0$ \\
\hline Günlük koşuşturmalardan kaçmak için & $22 / 6,4$ & $32 / 9,3$ & $53 / 15,4$ & $104 / 30,2$ & $133 / 38,7$ & $344 / 100,0$ \\
\hline Dinlenmek için & $20 / 5,8$ & $21 / 6,1$ & $46 / 13,4$ & $112 / 32,6$ & $145 / 42,2$ & $344 / 100,0$ \\
\hline Stres ve gerilimden kaçmak için & $11 / 3,2$ & $17 / 4,9$ & $44 / 12,8$ & $108 / 31,4$ & $164 / 47,7$ & $344 / 100,0$ \\
\hline Zamanımı rutinlikten çıarmak için & $11 / 3,2$ & $17 / 4,9$ & $46 / 13,4$ & $113 / 32,8$ & $157 / 45,6$ & $344 / 100,0$ \\
\hline
\end{tabular}

Tablo 5'in verileri incelendiğinde, ankete katılan öğrencilerin boş zamanlarını değerlendirme etkinliklerine katılımlarında en önemli ilk üç faktörün sırasıyla yeni fikirler edinmek $(\% 79,8)$, stres ve gerilimden kaçınmak $(\% 79,1)$ ve zamanlarını rutinlikten çıkarmak $(\% 78,4)$ olduğu görülmektedir. Aşağıdaki tablolarda ankete katılan öğrencilerin yaşadıkları bölgelere, demografik özelliklerine ve öğretim düzeylerine göre tercih ettikleri etkinlik türlerine ilişkin çapraz tablo analizleri yer almaktadır.

Tablo 6: Öğrencilerin Bölgelere Göre Boş Zaman Etkinlik Tercihlerine İlişkin Çapraz Tablo Analiz Değerleri

\begin{tabular}{|l|c|c|c|c|c|c|c|c|}
\hline \multirow{2}{*}{ ETKİNLIK TÜRÜ } & \multicolumn{9}{|c|}{ BÖLGELER } \\
\cline { 2 - 10 } & Marmara & Akdeniz & $\begin{array}{c}\text { İç } \\
\text { Anadolu }\end{array}$ & Karadeniz & Ege & $\begin{array}{c}\text { Doğu } \\
\text { Anadolu }\end{array}$ & $\begin{array}{c}\text { G.Doğu } \\
\text { Anadolu }\end{array}$ & TOPLAM \\
\hline Kitap, gazete okurum. & 6 & 2 & 23 & 28 & 1 & 0 & 4 & 64 \\
\hline Müzik dinlerim. & 5 & 1 & 20 & 37 & 1 & 0 & 0 & 64 \\
\hline TV izlerim. & 1 & 3 & 8 & 18 & 1 & 1 & 3 & 35 \\
\hline Sinema ve Tiyatroya giderim. & 8 & 1 & 4 & 6 & 1 & 0 & 0 & 20 \\
\hline $\begin{array}{l}\text { Çarşı, pazar, fuar, park gibi gezintilere } \\
\text { çıarım. }\end{array}$ & 8 & 3 & 15 & 25 & 1 & 2 & 1 & 55 \\
\hline Aktif olarak spor yaparım. & 6 & 3 & 8 & 10 & 2 & 0 & 0 & 29 \\
\hline $\begin{array}{l}\text { Beceri gerektiren el işleri ve sanatla } \\
\text { uğraşırım. }\end{array}$ & 1 & 1 & 4 & 10 & 0 & 0 & 0 & 16 \\
\hline $\begin{array}{l}\text { Spor yarışmalarını tesislere giderek } \\
\text { izlerim. }\end{array}$ & 0 & 0 & 0 & 1 & 0 & 0 & 0 & 1 \\
\hline $\begin{array}{l}\text { Sosyal ve toplumsal faaliyetlerle } \\
\text { uğrasıırım. }\end{array}$ & 1 & 0 & 3 & 4 & 0 & 0 & 0 & 8 \\
\hline Kültürel ve bilimsel faaliyetlere katılırım. & 0 & 0 & 1 & 2 & 0 & 0 & 0 & 3 \\
\hline Kafeye giderim. & 1 & 4 & 7 & 4 & 0 & 0 & 1 & 17 \\
\hline Belli bir şeyle uğraşmam. & 2 & 4 & 2 & 5 & 0 & 0 & 0 & 13 \\
\hline Arkadaş ziyaretlerine giderim. & 0 & 0 & 2 & 3 & 0 & 0 & 1 & 6 \\
\hline $\begin{array}{l}\text { Sosyal sorumluluk faaliyetleri yaparım } \\
\text { (ONKO-SAV, KAN-DER, TEGV, Sevgi } \\
\text { Evleri vb.) }\end{array}$ & 3 & 0 & 4 & 5 & 1 & 0 & 0 & 13 \\
\hline TOPLAM & 42 & 22 & 101 & 158 & 8 & 3 & 10 & 344 \\
\hline
\end{tabular}

Tablo 6'nın değerleri incelendiğinde ankete katılan öğrencilerin bölgelere göre oransal dağılımlarının sırasıyla \%45,9 Karadeniz, \%29,4 İç Anadolu, \%12,2 Marmara, \%6,40 Akdeniz, \%2,91 G. Doğu Anadolu, \%2,33 Ege ve \%0,87 Doğu Anadolu olduğu görülmektedir. Ankete katılan 344 öğrenci arasında en fazla tercih edilen etkinlik türlerinin kitap, gazete okuma, müzik dinleme ve çarşı, pazar, fuar, park gibi gezintilere çıkma olduğu söylenebilir. 
Tablo 7: Öğrencilerin Demografik Özelliklerine Göre Tercih Ettikleri Etkinlik Türlerine İlişkin Çapraz Tablo Değerleri

\begin{tabular}{|c|c|c|c|c|c|c|c|c|c|c|c|}
\hline \multirow{3}{*}{ ETKİNLİK TÜRÜ } & \multicolumn{11}{|c|}{ ÖĞRENCİLERIN DEMOGRAFİK ÖZELLIKLERİ } \\
\hline & \multicolumn{2}{|c|}{ CINSIYYT } & \multicolumn{4}{|c|}{ YAŞ } & \multicolumn{5}{|c|}{ GELIR } \\
\hline & Kadın & Erkek & $\begin{array}{c}18 \\
- \\
20\end{array}$ & $\begin{array}{c}21 \\
- \\
23\end{array}$ & $\begin{array}{c}24 \\
- \\
26\end{array}$ & $\begin{array}{c}27 \\
+\end{array}$ & $\begin{array}{c}400 \\
\text { TL'den } \\
\text { Az }\end{array}$ & $\begin{array}{c}401 \\
- \\
600\end{array}$ & $\begin{array}{c}601 \\
- \\
800\end{array}$ & $\begin{array}{c}801 \\
- \\
1000\end{array}$ & $\begin{array}{c}1001 \\
+\end{array}$ \\
\hline Kitap, gazete okurum. & 41 & 23 & 15 & 46 & 2 & 1 & 15 & 39 & 3 & 4 & 3 \\
\hline Müzik dinlerim. & 45 & 19 & 19 & 42 & 3 & 0 & 16 & 36 & 7 & 2 & 3 \\
\hline TV izlerim. & 26 & 9 & 13 & 19 & 3 & 0 & 9 & 21 & 2 & 0 & 3 \\
\hline Sinema ve Tiyatroya giderim. & 19 & 1 & 5 & 14 & 0 & 1 & 4 & 15 & 1 & 0 & 0 \\
\hline $\begin{array}{l}\text { Çarş1, pazar, fuar, park gibi } \\
\text { gezintilere çıkarım. }\end{array}$ & 40 & 15 & 13 & 37 & 5 & 0 & 13 & 31 & 5 & 4 & 2 \\
\hline Aktif olarak spor yaparım. & 14 & 15 & 6 & 22 & 1 & 0 & 5 & 16 & 2 & 2 & 4 \\
\hline $\begin{array}{l}\text { Beceri gerektiren el işleri ve } \\
\text { sanatla uğraşırım. }\end{array}$ & 12 & 4 & 3 & 13 & 0 & 0 & 3 & 10 & 2 & 1 & 0 \\
\hline $\begin{array}{l}\text { Spor yarışmalarını tesislere } \\
\text { giderek izlerim. }\end{array}$ & 0 & 1 & 0 & 1 & 0 & 0 & 0 & 0 & 0 & 1 & 0 \\
\hline $\begin{array}{l}\text { Sosyal ve toplumsal faaliyetlerle } \\
\text { uğraşırım. }\end{array}$ & 4 & 4 & 2 & 6 & 0 & 0 & 3 & 2 & 2 & 0 & 1 \\
\hline $\begin{array}{l}\text { Kültürel ve bilimsel faaliyetlere } \\
\text { katılırım. }\end{array}$ & 1 & 2 & 3 & 0 & 0 & 0 & 1 & 2 & 0 & 0 & 0 \\
\hline Kafeye giderim. & 14 & 3 & 5 & 10 & 2 & 0 & 4 & 6 & 5 & 0 & 2 \\
\hline Belli bir şeyle uğraşmam. & 9 & 4 & 3 & 8 & 2 & 0 & 4 & 5 & 2 & 1 & 1 \\
\hline Arkadaş ziyaretlerine giderim. & 3 & 3 & 0 & 5 & 1 & 0 & 1 & 4 & 1 & 0 & 0 \\
\hline $\begin{array}{l}\text { Sosyal sorumluluk faaliyetleri } \\
\text { yaparım } \\
\text { (ONKO-SAV, KAN-DER, } \\
\text { TEGV, Sevgi Evleri vb.) }\end{array}$ & 8 & 5 & 2 & 10 & 1 & 0 & 2 & 4 & 3 & 1 & 3 \\
\hline TOPLAM & 236 & 108 & 89 & 233 & 20 & 2 & 80 & 191 & 35 & 16 & 22 \\
\hline
\end{tabular}

Tablo 7’nin verileri incelendiğinde; ankete katılan öğrenciler arasında kadınların en çok tercih ettikleri etkinlik türü müzik dinleme iken, erkeklerin kitap, gazete okuma olduğu görülmektedir. Yaş grupları itibariyle tercih edilen etkinlik türleri incelendiğinde 18-20 yaş grubunda yer alan öğrencilerin en çok tercih ettikleri etkinlik türü müzik dinleme iken, 21-23 yaş grubundaki öğrenciler kitap, gazete okumayı, 24-26 yaş grubundaki öğrencilerin ise çarşı, pazar, fuar, park gibi gezintilere çıkmayı tercih ettikleri görülmektedir. Gelir düzeyine göre tercih edilen etkinlik türü incelendiğinde, ankete katılan ve 400 TL'den az gelire sahip olan öğrencilerin müzik dinleme ilk tercih ettikleri etkinlik türü olurken, 401-600 TL arası gelire sahip olan öğrencilerin ilk tercih ettikleri etkinlik türü kitap, gazete okuma olduğu görülmektedir. Gelir düzeyi arasında çok büyük farklılıkların olmaması, yaş grupları itibariyle benzer yaş aralıklarında olmaları nedeniyle ankete katılan öğrencilerin birbirlerine benzer boş zaman etkinliklerinde bulundukları söylenebilir. 
Tablo 8: Öğrencilerin Eğitim Düzeylerine Göre Tercih Ettikleri Etkinlik Türlerine İlişkin Çapraz Tablo Değerleri

\begin{tabular}{|c|c|c|c|c|c|c|c|c|c|c|c|}
\hline \multirow{3}{*}{ ETKİNLİK TÜRÜ } & \multicolumn{11}{|c|}{ ÖĞRENCİLERİN EĞİTIMM DÜZEYLERİ } \\
\hline & \multicolumn{2}{|c|}{$\begin{array}{l}\text { Program } \\
\text { Türü } \\
\end{array}$} & \multicolumn{4}{|c|}{ SINIF } & \multicolumn{5}{|c|}{ BÖLÜM } \\
\hline & N.Ö. & İ.Ö. & 1. & 2. & 3. & 4. & İşletme & İktisat & Maliye & SBKY & $\begin{array}{l}\text { Bankacılık } \\
\text { Finans }\end{array}$ \\
\hline Kitap, gazete okurum. & 53 & 11 & 7 & 19 & 18 & 20 & 5 & 23 & 15 & 11 & 10 \\
\hline Müzik dinlerim. & 61 & 3 & 14 & 16 & 21 & 13 & 12 & 12 & 8 & 16 & 16 \\
\hline TV izlerim. & 33 & 2 & 9 & 9 & 7 & 10 & 7 & 7 & 9 & 6 & 6 \\
\hline Sinema ve Tiyatroya giderim. & 18 & 2 & 4 & 4 & 4 & 8 & 0 & 4 & 4 & 6 & 6 \\
\hline $\begin{array}{l}\text { Çarş1, pazar, fuar, park gibi } \\
\text { gezintilere çıkarım. }\end{array}$ & 51 & 4 & 8 & 10 & 19 & 18 & 8 & 9 & 14 & 9 & 15 \\
\hline Aktif olarak spor yaparım. & 27 & 2 & 7 & 10 & 4 & 8 & 11 & 2 & 8 & 3 & 5 \\
\hline $\begin{array}{l}\text { Beceri gerektiren el işleri ve } \\
\text { sanatla uğraşırım. }\end{array}$ & 16 & 0 & 2 & 3 & 5 & 6 & 6 & 1 & 5 & 0 & 4 \\
\hline $\begin{array}{l}\text { Spor yarışmalarını tesislere } \\
\text { giderek izlerim. }\end{array}$ & 1 & 0 & 0 & 0 & 1 & 0 & 1 & 0 & 0 & 0 & 0 \\
\hline $\begin{array}{l}\text { Sosyal ve toplumsal } \\
\text { faaliyetlerle uğraşırım. }\end{array}$ & 7 & 1 & 0 & 3 & 1 & 4 & 2 & 2 & 2 & 1 & 1 \\
\hline $\begin{array}{l}\text { Kültürel ve bilimsel } \\
\text { faaliyetlere katılırım. }\end{array}$ & 3 & 0 & 2 & 0 & 0 & 1 & 0 & 0 & 2 & 1 & 0 \\
\hline Kafeye giderim. & 17 & 0 & 7 & 3 & 3 & 4 & 4 & 4 & 3 & 1 & 5 \\
\hline Belli bir şeyle uğraşmam. & 11 & 2 & 2 & 4 & 3 & 4 & 2 & 3 & 2 & 4 & 2 \\
\hline Arkadaş ziyaretlerine giderim. & 6 & 0 & 0 & 3 & 2 & 1 & 1 & 3 & 0 & 2 & 0 \\
\hline $\begin{array}{l}\text { Sosyal sorumluluk faaliyetleri } \\
\text { yaparım } \\
\text { (ONKO-SAV, KAN-DER, } \\
\text { TEGV, Sevgi Evleri vb.) }\end{array}$ & 10 & 3 & 1 & 4 & 5 & 3 & 2 & 2 & 2 & 3 & 4 \\
\hline TOPLAM & 314 & 30 & 63 & 88 & 93 & 100 & 61 & 72 & 74 & 63 & 74 \\
\hline
\end{tabular}

Tablo 8'in verileri incelendiğinde; N.Ö. programındaki öğrencilerin ilk tercih ettikleri etkinlik türü müzik dinlemek iken, İ.Ö. programındaki öğrencilerin kitap, gazete okumak olduğu görülmektedir. Öğrencilerin sınıflarına göre ilk tercih ettikleri etkinlik türü incelendiğinde 1. ve 3. sınıf öğrencilerinin müzik dinlemeyi, 2. ve 4. sinıf öğrencilerinin kitap, gazete okumayı, diğer etkinlik türlerine göre daha çok tercih ettikleri görülmektedir. Öğrencilerin eğitim gördükleri bölümlere göre ilk tercih ettikleri etkinlik türü incelendiğinde işletme, SBKY ve Bankacılık \& Finans bölümü öğrencilerinin müzik dinlemeyi, iktisat ve maliye bölümü öğrencilerinin kitap, gazete okumayı diğer etkinliklere göre daha çok tercih ettikleri görülmektedir. 
Tablo 9: Öğrencilerin Demografik Özelliklerine Göre Kümeleme Analizi Sonuçları

\section{Clusters}

Input (Predictor) Importance

$\square 1,0 \square 0,8 \square 0,6 \square 0,4 \square 0,2 \square 0,0$

\begin{tabular}{|c|c|c|c|c|}
\hline Cluster & 3 & 4 & 1 & 2 \\
\hline \multicolumn{5}{|l|}{ Labal } \\
\hline \multicolumn{5}{|l|}{ Description } \\
\hline Sire & $\begin{array}{r}30,5 \% \\
(105)\end{array}$ & $\begin{array}{r}25,6 \% \\
(88)\end{array}$ & $\begin{array}{r}23,3 x \\
(80)\end{array}$ & 20.63 \\
\hline \multirow[t]{9}{*}{ In puts } & 401-600 TL Tir $(83.8 \%)$ & 401-600 TL $(61.4 \%)$ & 400'den az $(82,5 \%)$ & $401-600$ TL TL $(69,0 \%)$ \\
\hline & $\begin{array}{c}\text { Cinsiyet } \\
\text { Kadin }(94,3 \%)\end{array}$ & $\begin{array}{l}\text { Cinsiyet } \\
\text { Erkek }(70,5 \%)\end{array}$ & $\begin{array}{l}\text { Cinsiyet } \\
\text { Kadin }(93.8 x)\end{array}$ & $\begin{array}{l}\text { Cinsiyet } \\
\text { Kadin (50.7 } x)\end{array}$ \\
\hline & $\begin{array}{c}\text { BošzamanEkinlik } \\
\text { Carșl-Pazar-Park } \\
\text { Gezisi (26.7\%) }\end{array}$ & $\begin{array}{c}\text { BoşZamanEkinlik } \\
\text { Kitap Okuma }(33,0 \%)\end{array}$ & $\begin{array}{c}\text { Bos ZamanEtkinlik } \\
\text { Mijzik Dinleme } \\
(21,2 \%)\end{array}$ & $\begin{array}{c}\text { Bos ZamanEtkinlik } \\
\text { Wuizik Dinleme } \\
(53,5 \%)\end{array}$ \\
\hline & 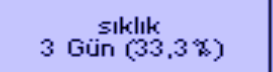 & 3 Gikelık & 2 Giklık & 7 gün $(38.0 \%)$ \\
\hline & iç Anade ikamet & $\begin{array}{l}\text { Aile ikamet } \\
\text { Karadeniz }(44,3 \%)\end{array}$ & $\begin{array}{l}\text { Aile ikamet } \\
\text { Karadeniz }(62.5 \%)\end{array}$ & $\begin{array}{c}\text { Aile ikamet } \\
\text { Karadeniz }(70.4 \%)\end{array}$ \\
\hline & 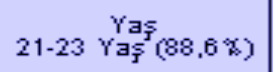 & $21-23 \underset{\gamma a_{S}}{\gamma}(47,7 \gamma)$ & $21-23 \gamma^{\gamma_{a s}}(52,5 x)$ & 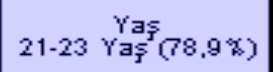 \\
\hline & 4. Sinıf $\operatorname{Sin}(41,9 x)$ & 2. Sinifiniz & 4. $\operatorname{Sin} \operatorname{Sin}(28.7 x)$ & 3. Sinılf $(33.8 x)$ \\
\hline & $\begin{array}{l}\text { ETÜR } \\
3.63\end{array}$ & $\begin{array}{l}\text { ETÜR } \\
3.40\end{array}$ & $\underset{3.52}{\text { ETüR }}$ & $\begin{array}{l}\text { ETüR } \\
3.27\end{array}$ \\
\hline & EKAT & EKAT & $\begin{array}{l}\text { EKAT } \\
3.71\end{array}$ & EKAT \\
\hline
\end{tabular}


Tablo 10: Kümeleme Analizinde Yer Alan Değişkenlerin Kümelerin Oluşmasındaki Önem Düzeyleri

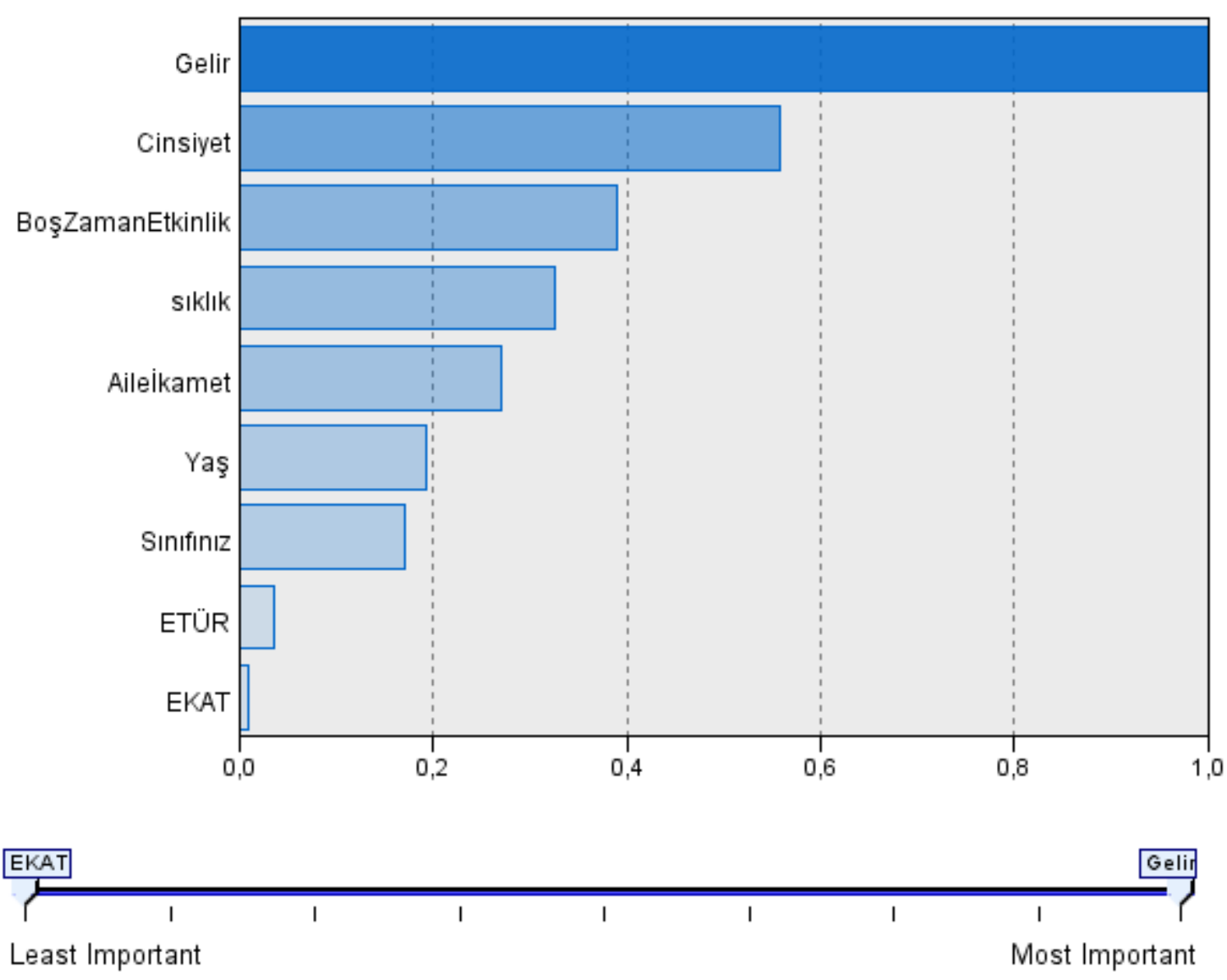

Tablo 9 ve Tablo 10'nun verileri incelendiğinde, ankete katılan öğrencilerin boş zamanlarını değerlendirme etkinliklerine göre kümelere ayrılmasında sırasıyla gelir düzeyi, cinsiyet, boş zamanlarını değerlendirdikleri etkinlik türü, etkinlikleri gerçekleştirme sıklıkları, öğrencilerin yaşadıkları bölge, yaş ve öğrenim gördükleri sınıf düzeyleri ile etkinlik türlerini seçmelerinde ve etkinliklere katılmalarında etkili olan faktörleri algılama düzeylerinin etkili olduğu görülmektedir.

Tablo 9'daki kümeleme analizi sonucuna göre ankete katılan öğrencilerin boş zamanlarını değerlendirme etkinliklerini tercihlerine göre kümelenmelerinde en önemli ilk üç unsurun sırasıyla gelir, cinsiyet gibi demografik faktörler ile tercih edilen etkinlik türü olduğu görülmektedir. Etkinlik türü seçiminde ya da etkinliğe katılımda etkili olan faktörlerin algılanma düzeylerinin ise kümelerin ayrılmasında en düşük etkiye sahip unsurlar olduğu söylenebilir.

Kümeleme analizi sonucunda ankete katılan öğrencilerin \%23,3'ünün 1. kümede, \%20,6'sının ikinci kümede, \%30,5'inin üçüncü kümede, \%25,6'sının da dördüncü kümede yer aldıkları görülmektedir. Birinci kümede yer alan öğrencilerin 400 TL'den daha az gelire sahip oldukları $(\% 82,5)$, kadın öğrencilerden oluştukları $(\% 93,8)$, boş zamanlarını müzik dinleyerek geçirmeyi tercih ettikleri (\%21,2), haftada 2 gün müzik dinlediklerini $(\% 27,5)$, Karadeniz bölgesinde ikamet ettikleri (\%62,5), 21-23 yaş aralığında bulundukları (\%52,5), 4. sınıfta 
öğrenim gördükleri $(\% 28,7)$, etkinlik türü seçiminde $(3,52)$ ve etkinliklere katılımlarında $(3,71)$ etkili olan faktörleri algılama düzeylerinin ortalamanın $(3,00)$ üzerinde olduğu görülmektedir.

İkinci kümede yer alan öğrencilerin 401-600 TL arasında gelir düzeyine sahip oldukları $(\% 69,0)$, kadın öğrencilerden oluştukları $(\% 50,7)$, boş zamanlarını müzik dinleyerek geçirmeyi tercih ettikleri $(\% 53,5)$, haftada 7 gün müzik dinledikleri $(\% 38,0)$, Karadeniz bölgesinde ikamet ettikleri $(\% 70,4), 21-23$ yaş aralığında bulundukları $(\% 78,9)$, 3. sınıfta öğrenim gördükleri $(\% 33,8)$, etkinlik türü seçiminde $(3,27)$ ve etkinliklere katılımlarında $(3,53)$ etkili olan faktörleri algılama düzeylerinin ortalamaya $(3,00)$ yakın düzeyde olduğu söylenebilir.

Üçüncü kümede yer alan öğrencilerin 401-600 TL arasında gelir düzeyine sahip oldukları $(\% 83,8)$, kadın öğrencilerden oluştukları $(\% 94,3)$, boş zamanlarını çarşı, Pazar, fuar, park gibi gezintilerle geçirmeyi tercih ettikleri $(\% 26,7)$, haftada 3 gün bu etkinliği gerçekleştirdikleri $(\% 33,3)$, İç Anadolu bölgesinde ikamet ettikleri (\%44,8), 21-23 yaş aralığında bulundukları $(\% 88,6), 4$. sınıfta öğrenim gördükleri $(\% 41,9)$, etkinlik türü seçiminde $(3,63)$ ve etkinliklere katılımlarında $(3,67)$ etkili olan faktörleri algılama düzeylerinin ortalamanın $(3,00)$ üzerinde olduğu söylenebilir.

Dördüncü kümede yer alan öğrencilerin 401-600 TL arasında gelir düzeyine sahip oldukları $(\% 61,4)$, erkek öğrencilerden oluştukları $(\% 70,5)$, boş zamanlarını kitap okuyarak geçirmeyi tercih ettikleri $(\% 33,0)$, haftada 3 gün kitap okudukları $(\% 37,5)$, Karadeniz bölgesinde ikamet ettikleri (\%44,3), 21-23 yaş aralığında bulundukları (\%47,7), 2. sınıfta öğrenim gördükleri $(\% 44,3)$, etkinlik türü seçiminde $(3,40)$ ve etkinliklere katılımlarında $(3,61)$ etkili olan faktörleri algılama düzeylerinin ortalamanın $(3,00)$ üzerinde olduğu söylenebilir.

Yukarıda anlatılan dört kümeye ilişkin bilgiler aşağıdaki grafiklerde görsel ve özet halinde verilmiştir. 


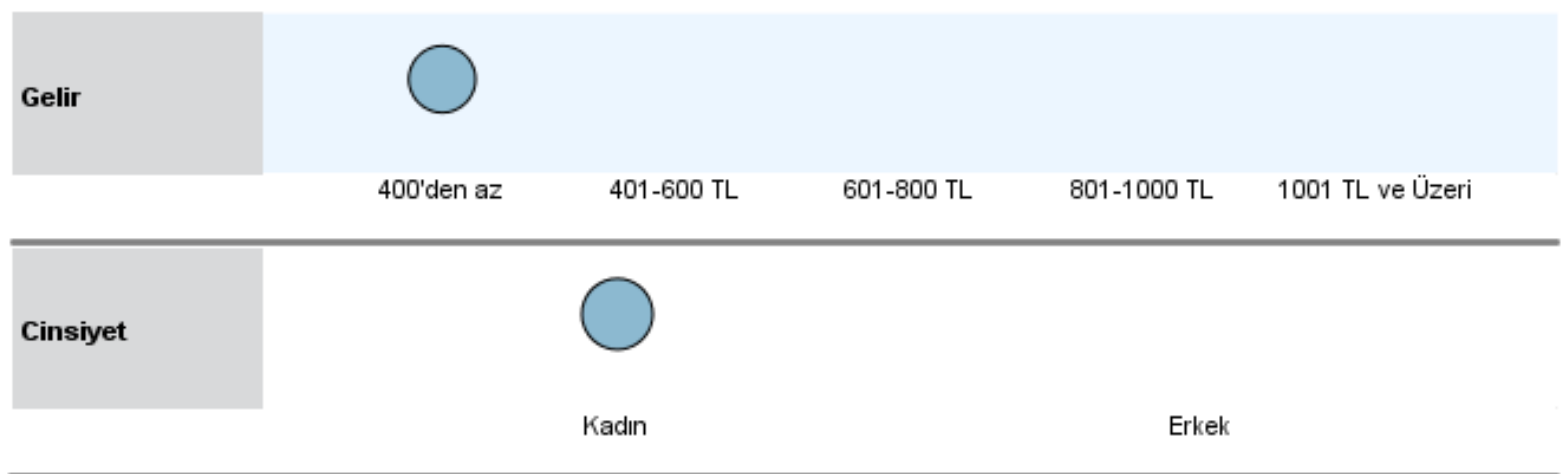

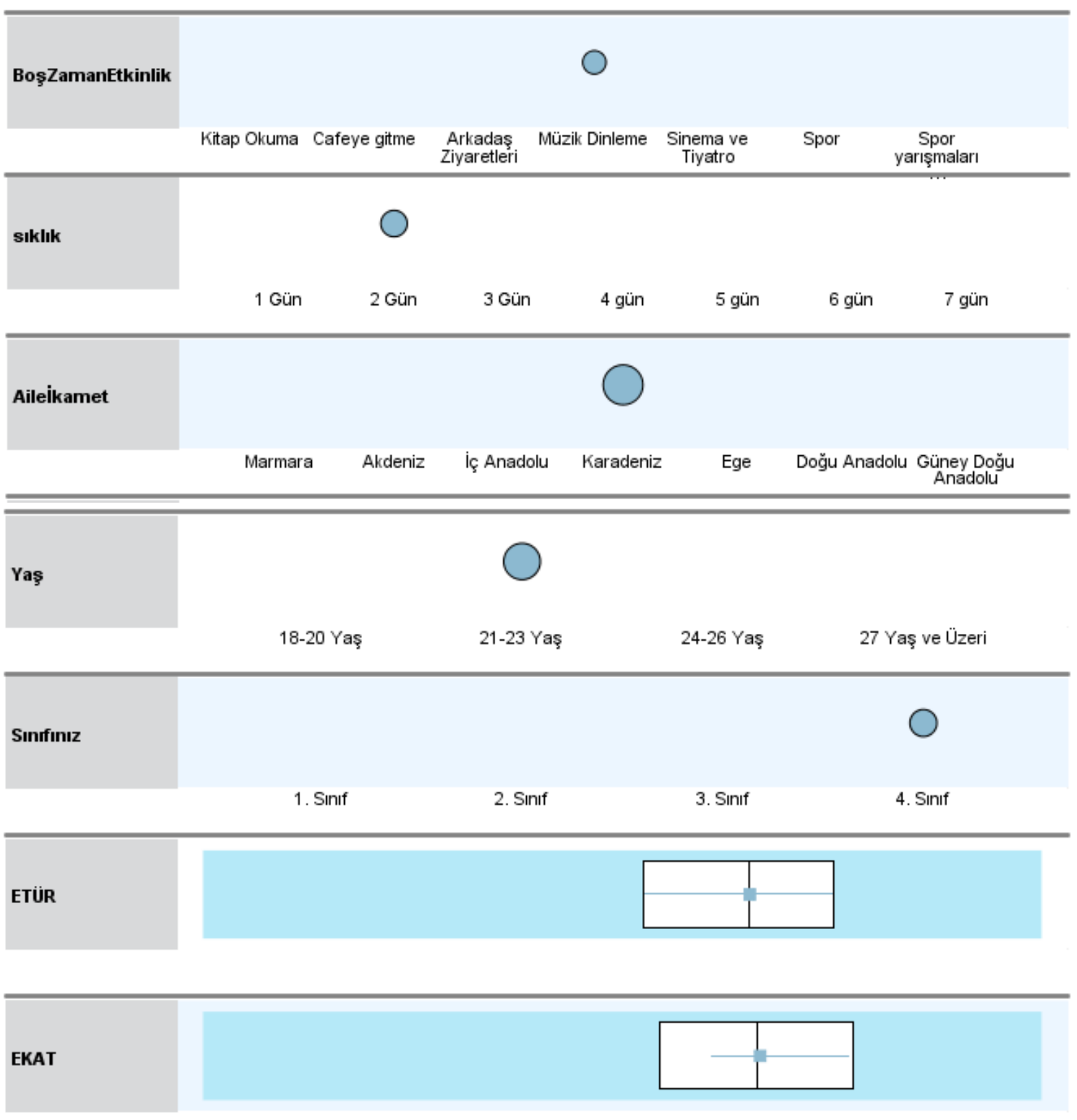




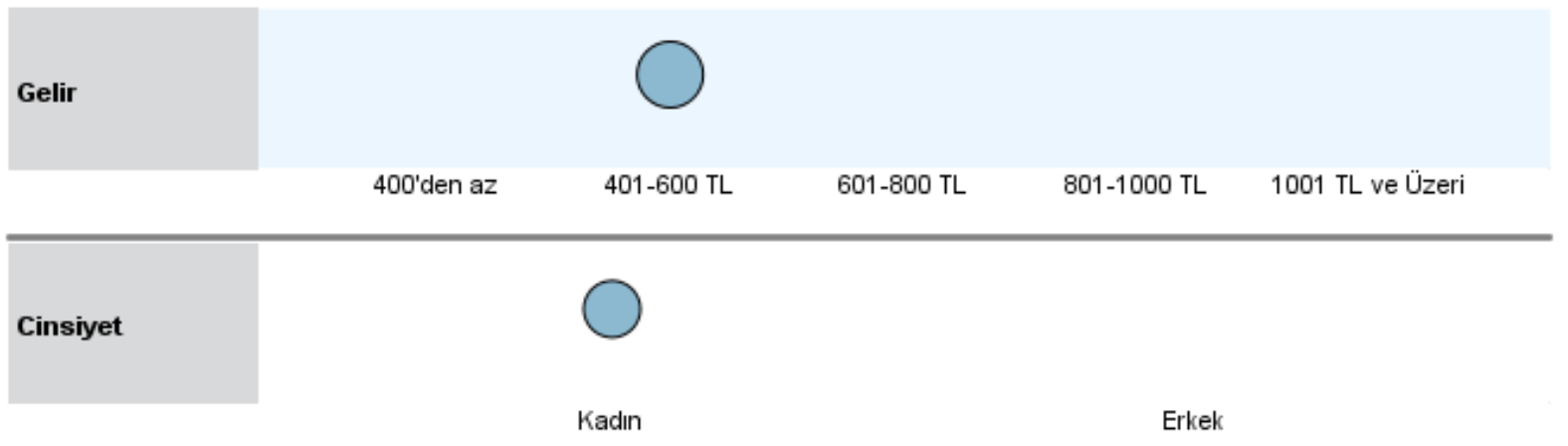

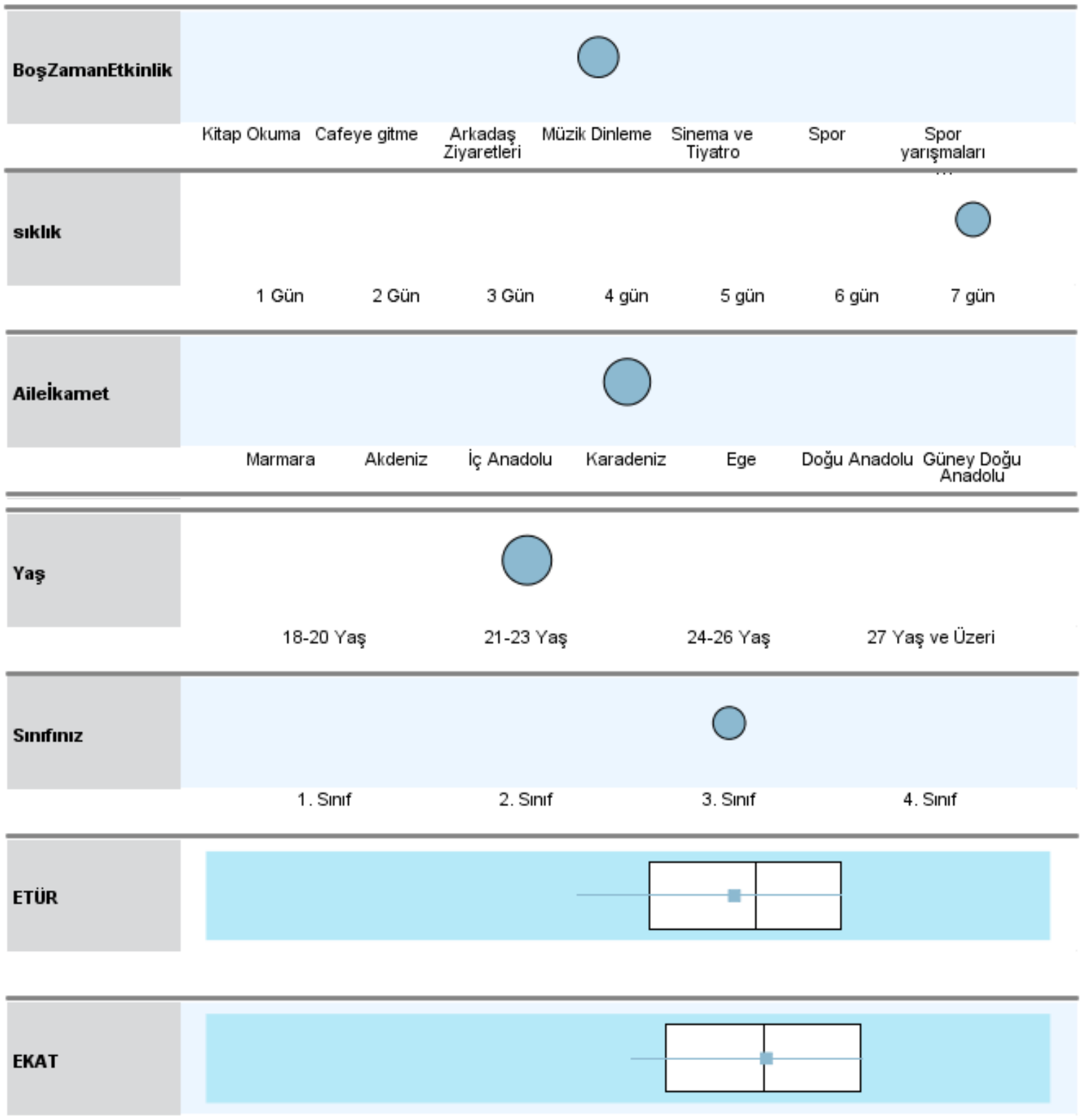



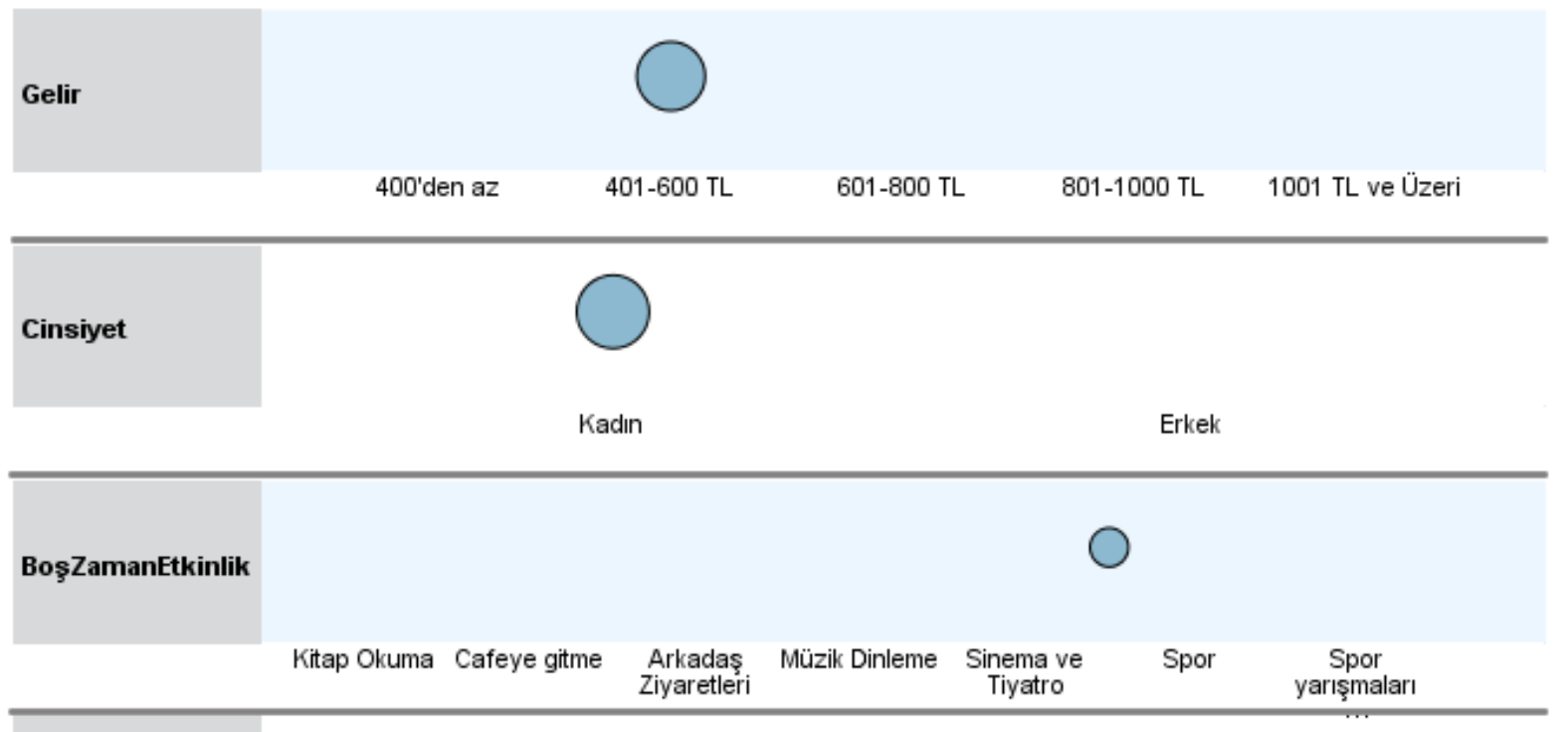

\begin{tabular}{llllll}
\hline sıkık & & & & \\
& & & & & \\
Gün & 2 Gün $\quad 3$ Gün $\quad 4$ gün & 5 gün & 6 gün & 7 gün \\
\hline
\end{tabular}

Aileikamet
Marmara Akdeniz iç Anadolu Karadeniz Ege Doğu Anadolu Güney Doğu
Anadolu

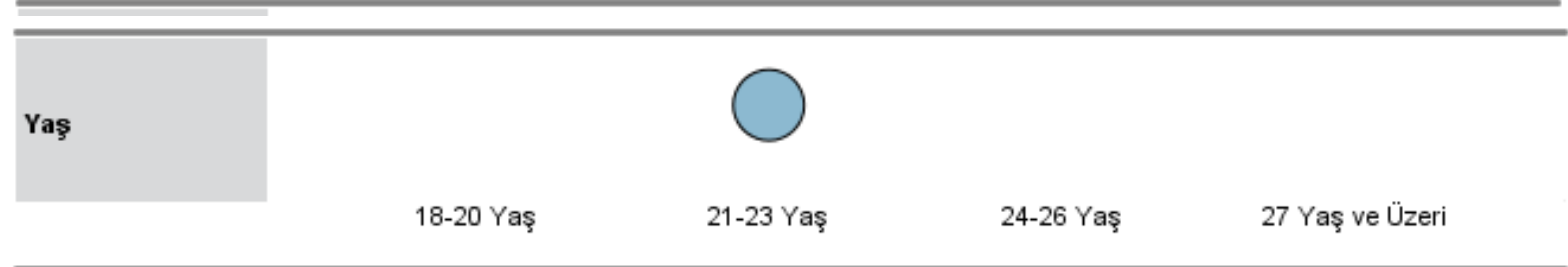

\begin{tabular}{|c|c|c|c|c|}
\hline \multicolumn{5}{|l|}{ Sınıfınız } \\
\hline & 1. Sinıf & 2. Sinif & 3. Sinif & 4. Sinif \\
\hline
\end{tabular}

\begin{tabular}{|l|l|l|l|}
\hline ETüR & \begin{tabular}{|l|l|}
\hline \\
\hline
\end{tabular} & \\
\hline
\end{tabular}

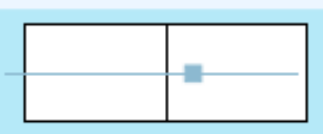




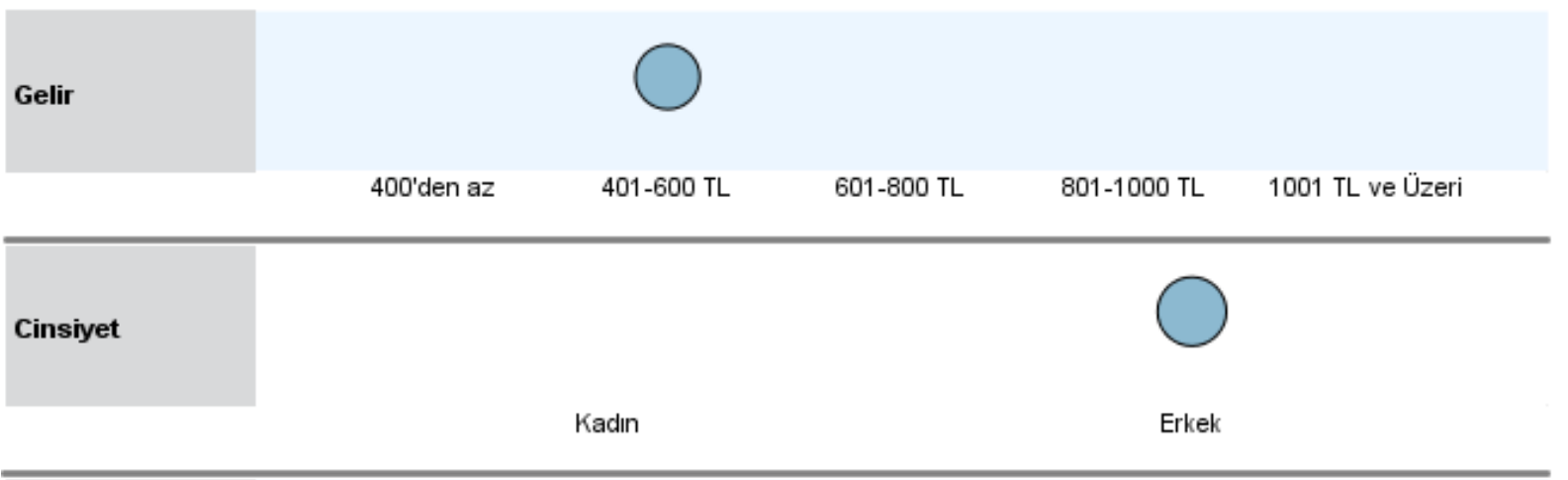

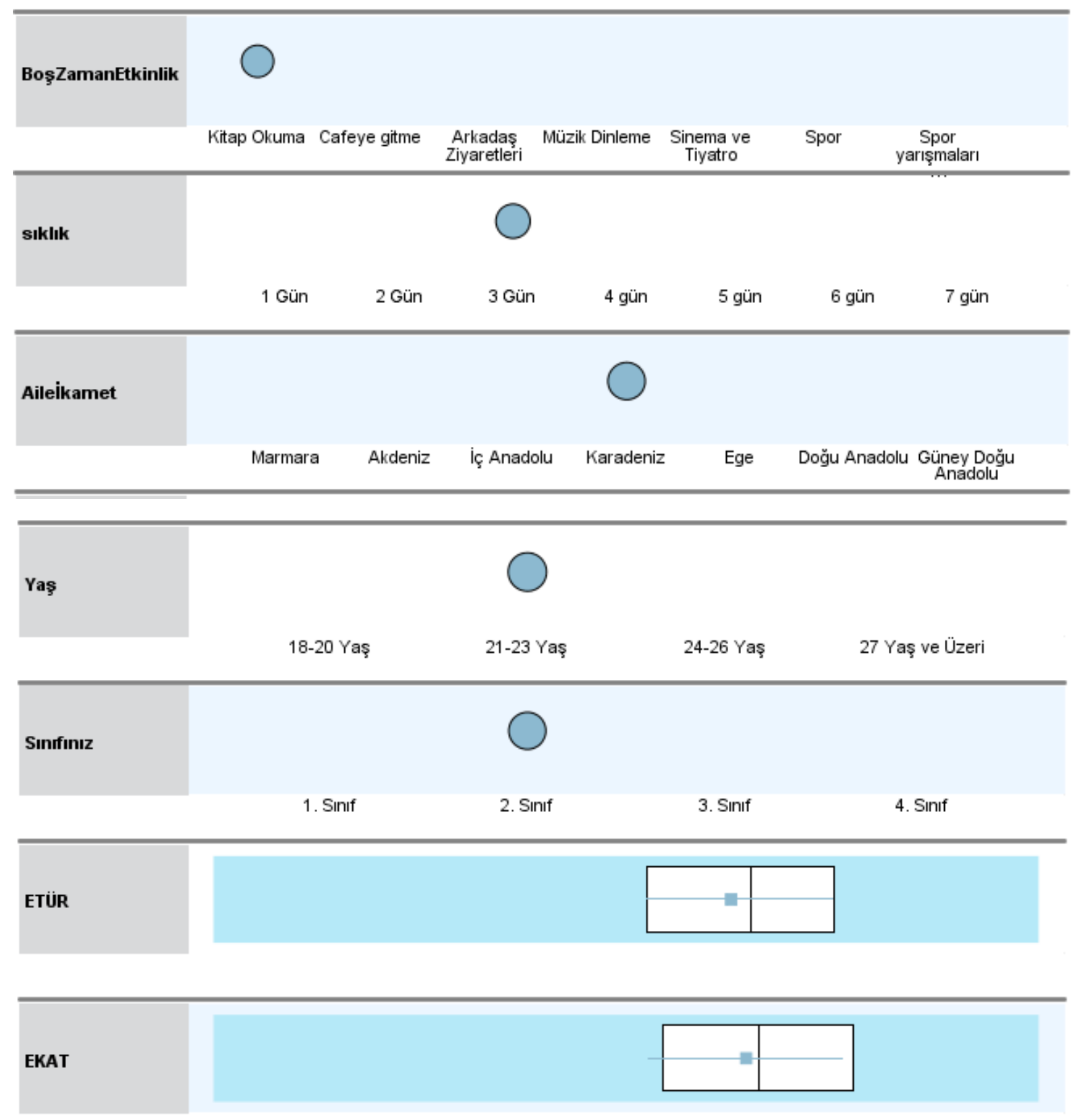




\section{Sonuç}

Çalışmanın amacı üniversite öğrencilerinin boş zaman değerlendirme etkinliklerine katılımlarında etkili olan faktörlerin değerlendirilerek, tercih edilen etkinlik türlerine göre kümeleme analizinin gerçekleştirilmesidir. Çalışma verileri Hitit Üniversitesi İktisadi ve İdari Bilimler fakültesinde öğrenim görmekte olan öğrencilere uygulanan anketler ile elde edilmiştir. Çalışma kapsamında öğrencilerin demografik özellikleri, öğretim düzeyleri, tercih ettikleri etkinlik türleri, etkinliklere katılım sıklıkları, etkinlik türlerini seçmelerinde etkili olan faktörler ile etkinliklere katılımlarında etkili olan faktörlere ilişkin değerlendirmelerde tanımlayıcı istatistiklerden yüzde, frekans ve çapraz tablo analizlerinden yararlanılmıştır. Öğrencilerin boş zaman değerlendirme etkinlikleri küme gruplarının oluşturulmasında iki kademeli küme analizi kullanılmıştır.

Analiz sonuçlarına göre, öğrencilerin boş zamanlarını değerlendirmek için en çok kitap okuma, müzik dinleme ve çarşı, pazar, park gibi gezintilere çıkma, en az ise spor yarışmalarını tesislerde izleme ve kültürel/bilimsel faaliyetlere katılma aktivitelerini tercih etmektedirler. Öğrencilerin \%61,1'i haftanın en az üç günü boş zamanlarını değerlendirmek için etkinliklerde bulunduklarını belirtmişlerdir. Öğrencilerin boş zaman değerlendirme etkinlik türlerinin seçiminde zamanının uygun olması ve kendilerini rahat hissetme faktörlerinin oldukça etkili olduğunu, televizyondaki sağlıklı yaşam programlarının ise etkisinin oldukça az olduğu görülmektedir. Öğrenciler boş zaman etkinliklerine, yeni fikirler edinmek, stresten ve gerilimde uzak durmak ve zamanlarını rutinlikten çıkarmak için katıldıklarını belirtmişlerdir.

Çalışmanın kavramsal modeline göre öğrencilerin demografik özelliklerinin boş zaman değerlendirme etkinlik tercihlerinin etkilediğini söylemek mümkündür. Öğrencilerin ikamet ettikleri bölgelere göre boş zaman değerlendirme etkinlik tercihleri incelendiğinde, Karadeniz Bölgesi ve İç Anadolu Bölgeleri'nde ikamet eden öğrencilerin en çok kitap, gazete okuma, Marmara bölgesinde ikamet eden öğrencilerin sinema tiyatroya gitme ve çarş1, park gezme, Akdeniz Bölgesinde ikamet eden öğrencilerin kafeye gitme, Ege Bölgesinde ikamet eden öğrencilerin aktif spor yapma, Doğu Anadolu Bölgesinde ikamet eden öğrencilerin çarşı, pazar, park gibi gezilere çıkma, Güney Doğu Anadolu Bölgesi’nde yaşayan öğrencilerin ise müzik dinleme ve televizyon izleme etkinlikleri en çok tercih ettikleri görülmektedir. Kız öğrencilerin en çok boş zamanlarını değerlendirirken müzik dinledikleri, erkek öğrencilerin ise kitap okudukları söylenebilir. Yaş grupları itibariyle tercih edilen etkinlik türleri incelendiğinde 1820 yaş grubunda yer alan öğrencilerin en çok tercih ettikleri etkinlik türü müzik dinleme iken, 21-23 yaş grubundaki öğrenciler kitap, gazete okumayı, 24-26 yaş grubundaki öğrencilerin ise çarşı, pazar, fuar, park gibi gezintilere çıkmayı tercih ettikleri görülmektedir. Gelir düzeyine göre tercih edilen etkinlik türü incelendiğinde, ankete katılan ve 400 TL'den az gelire sahip olan öğrencilerin müzik dinleme ilk tercih ettikleri etkinlik türü olurken, 401-600 TL aras1 gelire sahip olan öğrencilerin ilk tercih ettikleri etkinlik türü kitap, gazete okuma olduğu görülmektedir. Gelir düzeyi arasında çok büyük farklılıkların olmaması, yaş grupları itibariyle benzer yaş aralıklarında olmaları nedeniyle ankete katılan öğrencilerin birbirlerine benzer boş zaman etkinliklerinde bulundukları söylenebilir.

Öğrencilerin demografik özelliklerinin yanı sıra öğrenim düzeylerinin de boş zamanlarını değerlendirme etkinlik tercihinde değişiklik yarattığını söylemek mümkündür. Analiz sonuçları incelendiğinde 1. ve 3. Sınıf öğrencilerinin müzik dinlemeyi, 2. ve 4. Sınıf öğrencilerinin kitap, gazete okumayı, diğer etkinlik türlerine göre daha çok tercih ettikleri görülmektedir. Öğrencilerin eğitim gördükleri bölümlere göre ilk tercih ettikleri etkinlik türü incelendiğinde işletme, SBKY ve Bankacılık \& Finans bölümü öğrencilerinin müzik dinlemeyi, iktisat ve maliye bölümü öğrencilerinin kitap, gazete okumayı diğer etkinliklere göre daha çok tercih ettikleri görülmektedir. 
Çalışmada öğrencilerin boş zaman değerlendirme etkinlik tercihlerindeki benzerliklerin ortaya konulmasıyla amacıyla kümeleme analizi uygulanmıştır. Öğrencilerin boş zamanlarını değerlendirme etkinliklerine göre kümelere ayrılmasında gelir düzeyi, cinsiyet, boş zamanlarını değerlendirdikleri etkinlik türü, etkinlikleri gerçekleştirme sıklıkları, öğrencilerin ikamet ettikleri bölge, yaş ve öğrenim gördükleri sınıf ile etkinlik türlerini seçmelerinde ve etkinliklere katılımlarında etkili olan faktörleri algılama düzeylerinin etkili olduğu söylenebilir. Analiz sonuçlarına göre öğrencilerin boş zaman değerlendirme tercihlerinin en çok katılımcıların demografik özelliklerinde gelir ve cinsiyet ile boş zamanlarını değerlendirmek için tercih ettikleri etkinlik türü olduğu belirlenmiştir.

Sonuç olarak bireyler boş zamanlarını etkili ve verimli bir şekilde değerlendirmek için çeşitli etkinleri tercih etmektedirler. Bireylerin bu tercihlerinde demografik özellikler, öğrenim durumları, etkinliklerden faydalanma sıklıkları, etkinlikleri tercih etme düzeyleri ve etkinliklere katılım düzeyleri etkili olmaktadır. Bu çalışmada boş zaman değerlendirme etkinliklerinin belirlenmesinde etkili olan faktörlerin belirlenmesinde kümeleme analizinden faydalanılmıştır. Çalışma analizleri sonucunda elde edilen bulgular göz önünde bulundurularak şehirlerin ve yükseköğretim kurumlarının idari yöneticilerine marka şehir ve marka üniversiteler yaratılabilmesi için öğrencilerin boş zaman değerlendirme etkinlik tercihleri ve tercihlerinde etkili olan faktörleri göz önünde bulundurarak sosyal, psikolojik ve fiziksel etkinler geliştirmeleri önerilebilir. Öyle ki öğrencilerin boş zamanlarını daha verimli geçirebilmeleri amacıyla, atölye çalışmaları, öğrenci kulüpleri aracılığıyla ortaöğretim öğrencileriyle ortak projelerin geliştirilmesi, üniversitenin bulunduğu ildeki sivil toplum örgütleriyle ve kamu kurumlarıyla ortak çalışmaların yapılması sağlanabilir. Üniversitelerin öğrenci kulüpleri, öğrencilerin akademik zamanları dışında kalan boş zamanlarını etkili ve verimli kullanmaları açısından faydalı topluluklardır. Bu sayede öğrenciler hem boş zamanlarını değerlendirme fursatı bulmuş hem de katıldıkları etkinlikleri gelecekte iş başvurularında CV'lerine ekleme imkânı sağlamış olmaktadırlar.

\section{Kaynakça}

Arslan, S. (2010). Yetişkin kent halkının belediyelerin serbest zaman eğitimi ile rekreasyon etkinliklerinin sunumuna ve yaşam kalitesine etkisine ilişkin görüşleri (Ankara Büyükşehir Belediyesi örneği) (Doktora tezi). Erişim adresi: file://C:/Users/User/Downloads/279922.pdf

Beard, J. G. \& Ragheb, M. G. (1980). Measurement Leisure Satisfaction, Journal of Leisure Research. 12(1), 20-33.

Erenci, T. (2006). Bir üniversite yerleşkesinde rekreasyon ihtiyacı ve planlaması (Umuttepe örneği). (Yüksek lisans tezi). Erişim adresi: file:///C:/Users/User/Downloads/194174.pdf

Karaküçük, S. (2008). Rekreasyon Boş Zamanları Değerlendirme, Gazi Kitapevi, Ankara.

Karatoprak, C.; İlgar, Y. ve Ballı, Ö. (2012). Kent içi rekreasyon parklarının rekreasyon potansiyelinin belirlenmesi. Antalya: I. Rekreasyon Araştırmaları Kongresinde sunulan bildiri. Kemer, Antalya. Erişim adresi: http://anatoliajournal.com/turizmkulliyati/ ulusalkongreler/rekreasyon1.pdf

Kılbaş, Ş. (2004). Rekreasyon Boş Zamanları Değerlendirme, Nobel Yayın Dağıtım, Ankara.

Kır, İ. (2007).Yüksek Öğretim Gençliğinin Boş Zaman Etkinlikleri: KSÜ Örneği. Kahra Fırat Üniversitesi Sosyal Bilimler Dergisi, 17(2), 307-328

Mengütay, S., \& Ağılönü, A. (2009). Yerel Yönetimlerde Rekreasyon Hizmetleri ve Model Belirleme. Uluslararası Ínsan Bilimleri Dergisi. 6(2), 160 - 175. 
Sabbağ, Ç., \& Aksoy, E. (2011). Üniversite öğrencileri ve çalışanların boş zaman etkinlikleri: Adıyaman örneği. Mehmet Akif Ersoy Üniversitesi Sosyal Bilimler Enstitüsü Dergisi, (4), 10-23.

Schrag, K. \& Strattman, K. (2009). Free-time Literacy Activities. Proceedings of the 5th Annual GRASP Symposium, Communication Sciences and Disorders. College of Health Professions, Wichita State University, pp:156-157.

Tekin, M., Yıldız, M., Akyüz, M. \& Uğur, O.A. (2008). Karaman Yüksek Öğrenim Kredi Ve Yurtlar Kurumunda Kalan Üniversite Öğrencilerinin Rekreatif Etkinliklere Katılım Ve Beklentilerinin İncelenmesi. Erzincan Eğitim Fakültesi Dergisi, 9(1), 121-135.

Terzioğlu, A. \& Yazıcı, M. (2003). Üniversite Öğrencilerinin Boş Zamanlarını Değerlendirme Anlayış ve Alışkanlıkları (Atatürk Üniversitesi Örneği), Erzincan Eğitim Fakültesi Dergisi, 5(2), 1-31.

Tezcan, M. (1972). Boş Zamanlar Sosyolojisi, Doğan Matbaası, Ankara. 